Document downloaded from:

http://hdl.handle.net/10251/119855

This paper must be cited as:

Kaushik, P.; Gramazio, P.; Vilanova Navarro, S.; Raigón Jiménez, MD.; Prohens Tomás, J.; Plazas Ávila, MDLO. (2017). Phenolics content, fruit flesh colour and browning in cultivated eggplant, wild relatives and interspecific hybrids and implications for fruit quality breeding. Food Research International. 102:392-401. https://doi.org/10.1016/j.foodres.2017.09.028

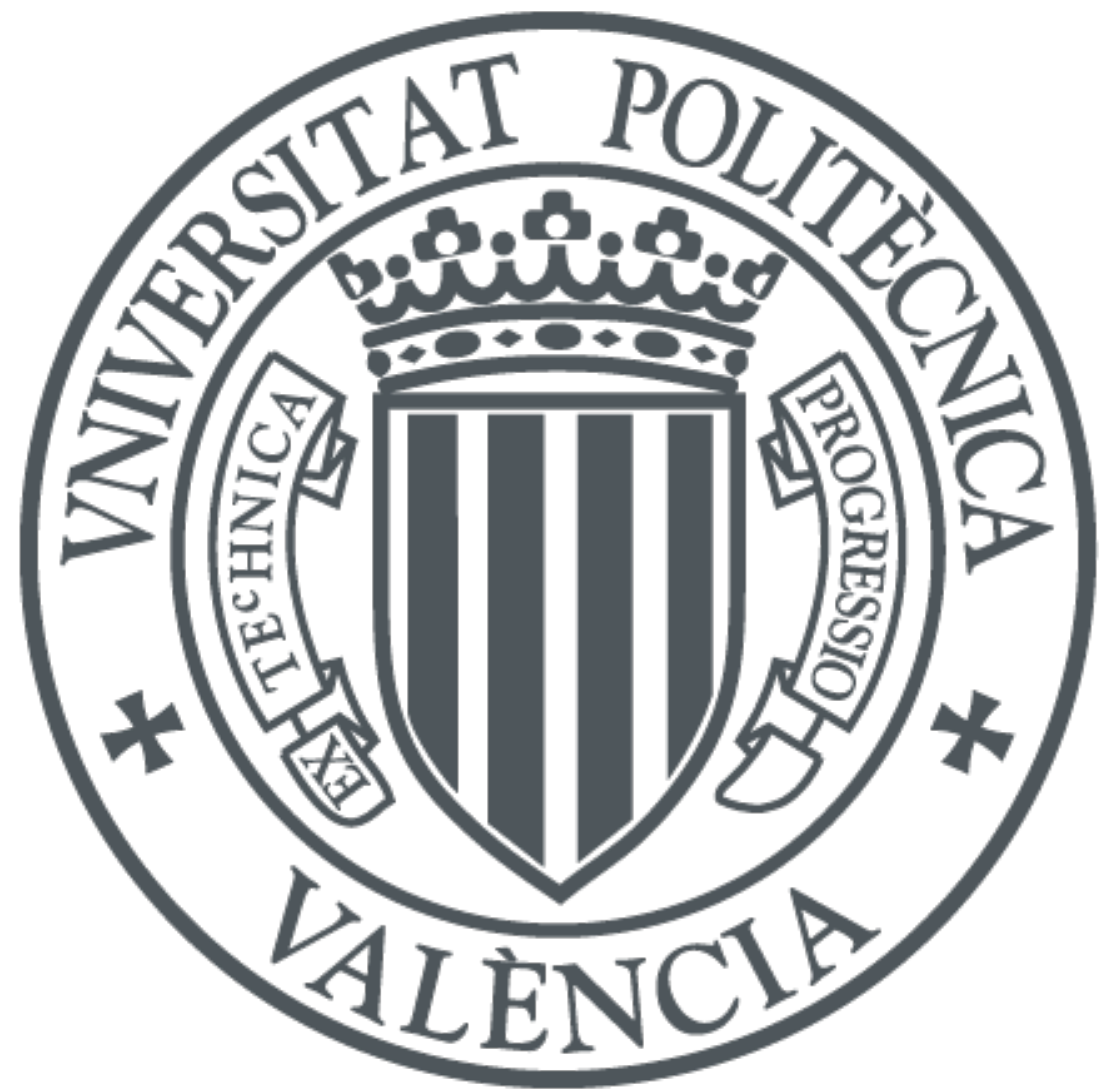

The final publication is available at

https://doi.org/10.1016/j.foodres.2017.09.028

Copyright Elsevier

Additional Information 


\section{Phenolics content, fruit flesh colour and browning in cultivated eggplant, wild relatives and interspecific hybrids and implications for fruit quality breeding}

Prashant Kaushik a, Pietro Gramazio a , Santiago Vilanova a , María D. Raigón ${ }^{\text {b }}$, Jaime Prohens ${ }^{\text {a,* }}$, Mariola Plazas ${ }^{\mathrm{c}}$

${ }^{a}$ Instituto de Conservación y Mejora de la Agrodiversidad Valenciana, Universitat Politècnica de València, Camino de Vera 14, 46022 Valencia, Spain

${ }^{\mathrm{b}}$ Departamento de Química, Universitat Politècnica de València, Camino de Vera 14, 46022 Valencia, Spain

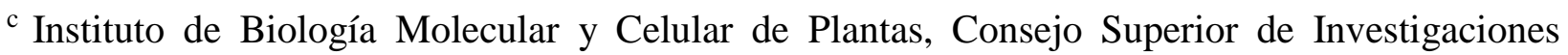
Científicas-Universitat Politècnica de València, Camino de Vera 14, 46022 Valencia, Spain

* Corresponding author.

E-mail addresses: prakau@doctor.upv.es (P. Kaushik), piegra@upv.es (P. Gramazio), sanvina@upvnet.upv.es (S. Vilanova), mdraigon@qim.upv.es (M.D. Raigón), jprohens@btc.upv.es (J. Prohens), maplaav@btc.upv.es (M. Plazas) 


\begin{abstract}
Increasing the content in bioactive phenolics in the eggplant (Solanum melongena) fruit is of interest, but may result in enhanced browning. We evaluated six varieties of S. melongena, 22 accessions of wild related species and 42 interspecific hybrids between cultivated eggplant and wild relatives for phenolics content, fruit flesh colour, polyphenol oxidase (PPO) activity, and fruit flesh browning. Wild relatives generally had a higher content in phenolics and a broader range of variation than cultivated eggplant. Chlorogenic acid was the predominant $(>65.0 \%)$ phenolic acid in cultivated eggplant and its primary genepool wild ancestor S. insanum, while for the other wild species on average represented less than $50 \%$ of the chromatogram peak area. Fruit flesh colour was lighter in S. melongena than in the wild species, while PPO activity and browning was much higher in wild species of the secondary and tertiary genepools. Interspecific hybrids between $S$. melongena and S. insanum were intermediate in their characteristics, while those with secondary and tertiary genepool species were more similar to the wild species. No significant correlations were found between total phenolics or chlorogenic acid contents and fruit flesh browning, but PPO activity was correlated to both the degree of browning $(r=0.404)$ and colour difference $(r=0.458)$. The results indicate that wild species can contribute to improving the bioactive properties of eggplant without affecting negatively fruit flesh colour and browning.
\end{abstract}

Keywords:

Browning

Chlorogenic acid

Hybrids

Phenolics 


\section{Solanum melongena}

Wild species

\section{Introduction}

Eggplant (Solanum melongena L.) is receiving increased attention for its various beneficial bioactive properties, which mostly derive from the high contents in phenolics in the fruit flesh (Mennella et al., 2010; Plazas et al., 2013a; Docimo et al., 2016a). Among them, chlorogenic acid (5-O-caffeoyl-quinic acid), a derivative of cinnamic acid, is generally the most abundant phenolic (Stommel \& Whitaker, 2003; Mennella et al., 2012; Prohens et al., 2013). Chlorogenic acid has anti-carcinogenic, anti-inflammatory, anti-microbial, anti-obesity, cardioprotective, hypotensive, and neuroprotective effects (Plazas et al., 2013a; Heleno, Martins, Queiroz, \& Ferreira, 2015). Because of this, interest in the development of vegetable crop varieties with high contents of chlorogenic acid and other phenolic acids has increased in the last years (Kaushik et al., 2015).

An important a drawback of increasing the content in chlorogenic acid in eggplant fruits is that it may result in enhanced fruit flesh browning (Prohens, Rodríguez-Burruezo, Raigón, \& Nuez, 2007; Plazas et al., 2013b; Mishra, Gautam, \& Sharma, 2013; Prohens et al., 2013). Enzymatic browning of the eggplant fruit flesh is caused by the action of polyphenol oxidases (PPOs), which catalyze the conversion of phenolic acids, stored in vacuoles, to quinones which react with oxygen to give brown coloured compounds (Mishra, Gautam, \& Sharma, 2013; Docimo et al., 2016b). Because of this, it has been hypothesized that selection for reduced browning has resulted in the indirect selection for lower content in phenolics acids in the eggplant fruit flesh of 
modern varieties (Prohens, Rodríguez-Burruezo, Raigón, \& Nuez, 2007; Meyer et al., 2015). As a main player in the browning process, variation in the PPO activity, which can be variable in the eggplant fruit flesh (Plazas et al., 2013b), may influence the degree of browning.

Various traits related to content in phenolics and fruit flesh browning have been studied in different eggplant materials (Mennella et al., 2010; Mishra, Gautam, \& Sharma, 2012; Mennella et al., 2012; Mishra, Gautam, \& Sharma, 2013; Plazas et al., 2013b; Prohens et al., 2013; Uchida, Tomita, Takemori, \& Takamura, 2017). In several crops, it has been found that browning and concentration in phenolics are positively correlated (Urbany et al., 2011; Di Guardo et al., 2013; Nayak, Liu, \& Tang, 2015). In eggplant, the correlation between fruit flesh phenolics concentration, and particularly chlorogenic acid content, and fruit flesh browning has been found to be moderate (Prohens, Rodríguez-Burruezo, Raigón, \& Nuez, 2007; Plazas et al., 2013b; Docimo et al., 2016a, 2016b), suggesting that other physiological or cell morphology factors may be involved in the browning process (Prohens, Rodríguez-Burruezo, Raigón, \& Nuez, 2007; Mishra, Gautam, \& Sharma, 2012; Docimo et al., 2016b).

Eggplant crop wild relatives from the primary, secondary and tertiary genepools contain a tremendous amount of underexploited genetic diversity for eggplant breeding (Knapp, Vorontsova, \& Prohens, 2013; Vorontsova, Stern, Bohs, \& Knapp, 2013; Plazas et al., 2016; Syfert et al., 2016). Breeders have emphasized the interest of exploiting them for their use for breeding against several biotic and abiotic stresses (Daunay \& Hazra, 2012; Rotino et al., 2014). Recently, Plazas et al. (2016) and Kouassi et al. (2016) have developed interspecific hybrids of six eggplant accessions with 14 wild species belonging to the primary, secondary and tertiary genepools, many of which have been morphologically characterized (Kaushik, Prohens, Vilanova, Gramazio, \& Plazas, 2016). 
Some wild relatives of eggplant are reported to have high contents in phenolic acids in the fruit flesh (Stommel \& Whitaker, 2003; Ma, Whitaker, \& Kennelly, 2010; Mennella et al., 2012; Prohens et al., 2013; Meyer et al., 2015; Kaur, Nagal, Nishad, Kumar, \& Sarika, 2014) and could be a source of variation for improved content in phenolics of the cultivated eggplant (Prohens et

al., 2013). However, little is known about the diversity among wild species for the content of phenolics and, to our knowledge, there are no studies related to either the fruit flesh colour and browning and PPO activity or to the relationship between content in phenolics and fruit flesh browning in collections of wild eggplants.

In this work, we characterize cultivated eggplant, wild relatives from the primary, secondary and tertiary genepools, along with interspecific hybrids between eggplant and some of the crop wild relatives for various traits related to content in phenolics and fruit flesh browning. Our work will provide relevant information on the potential of wild relatives for the development of eggplant cultivars with improved content in bioactive phenolics coupled with low fruit flesh browning.

\section{Material and Methods}

\subsection{Plant material}

Phenotypically diverse material (Kaushik, Prohens, Vilanova, Gramazio, \& Plazas, 2016) consisting of eggplant accessions, wild relatives, and interspecific hybrids were used for this study. The cultivated eggplant was represented by six eggplant (S. melongena) accessions (Table 1). For wild species, a total of 22 accessions from 13 species from the three eggplant genepools (Syfert et 
al., 2016) were also used (Table 1). Of these, three accessions belong to the primary genepool species $S$. insanum L., 13 to secondary genepool species $S$. anguivi Lam. (n=2), $S$. campylacanthum Hochst. ex A. Rich. (n=2), S. dasyphyllum Schumach. \& Thonn. (n=1), S. incanum L. (n=1), S. lichtensteinii Willd. (n=2), S. linnaeanum Hepper \& P.-M. L. Jaeger $(\mathrm{n}=2)$, S. pyracanthos Lam. $(\mathrm{n}=1)$, S. tomentosum $\mathrm{L}$. $(\mathrm{n}=1)$, and $S$. violaceum Ortega $(\mathrm{n}=1)$, and six to tertiary genepool species $S$. elaeagnifolium Cav. (n=2), S. sisymbriifolium Lam. $(\mathrm{n}=2)$, and $S$. torvum $\mathrm{Sw} .(\mathrm{n}=2)$. The cultivated eggplant and wild related species accessions from primary and secondary genepools were used to generate interspecific hybrids based on reciprocal crossing (Plazas et al., 2016; Kaushik, Prohens, Vilanova, Gramazio, \& Plazas, 2016), of which we used 18 hybrids with primary genepool wild species $S$. insanum and 24 hybrids with secondary genepool wild species, respectively. Five plants per accession or hybrid were grown under open field conditions at the agricultural experimental farm of Universitat Politècnica de València (Valencia, Spain: latitude, $39^{\circ} 28^{\prime} 55^{\prime \prime} \mathrm{N}$; longitude, $0^{\circ} 22^{\prime} 11^{\prime \prime} \mathrm{W}$; altitude: 4 masl) during the summer season of 2015 using standard horticultural practices for the eggplant crop.

\subsection{Sample preparation}

For each accession, three samples were used, each one consisting of five fruits collected at the developmental stage considered as commercially ripe (i.e., physiologically immature) for cultivated eggplant. Fruits were processed by cutting them transversally with a knife at halfway between the distal and proximal part of the fruit. One-half of the fruit was used to measure fruit flesh browning, while for the other half a transversal slice (or the whole half for small fruits) was 
cut from the middle part of the fruit, peeled, frozen immediately with liquid $\mathrm{N}_{2}$ and kept at $-80{ }^{\circ} \mathrm{C}$ until lyophilized.

\subsection{Dry matter and phenolics}

Homogenized tissue of each sample, consisting of an equivalent weight of each of the five fruits that make up a sample, was used for the chemical analyses except for dry matter analysis. Dry matter was measured for fresh fruit samples as the change of weight before and after lyophilisation based on the formula $100 \times($ dry weight/fresh weight $)$ and expressed as percentage of dry weight (dw). Total phenolics content (mg/g dw) was determined using the Folin-Ciocalteu method (Singleton \& Rossi, 1965) after extraction with acetone (70\% v/v) and acetic acid (0.5\% v/v). Absorbance was measured at $750 \mathrm{~nm}$ with a spectrophotometer (Jenway, Essex, UK) and chlorogenic acid (Sigma-Aldrich Chemie, Germany) was used as a standard, as this is the most common phenolic compound of the eggplant fruit flesh (Stommel \& Whitaker, 2003; Docimo et al., 2016a). For chlorogenic acid content determination, powdered samples $(0.1 \mathrm{~g})$ were homogenized in $1.8 \mathrm{~mL}$ of methanol:water $(80: 20, \mathrm{v} / \mathrm{v})$ plus $0.1 \%(\mathrm{w} / \mathrm{v})$ of 2,3-tert-Butyl-4hydroxyanisole (BHT) and subsequently filtered through $0.2-\mu \mathrm{m}$ polytetrafluoroethylene (PTFE) membrane filters. A standard solution of chlorogenic acid was used as control. High-performance liquid chromatography (HPLC) was performed for determination of chlorogenic acid content (mg/g dw) according to the protocol of Plazas et al. (2014). Extracts were analyzed on a 1220 Infinity LC System (Agilent Technologies, Santa Clara, CA, USA) operated by the OpenLAB CDS ChemStation Edition software package (Agilent Technologies) using manufacturer's instructions. The chlorogenic acid peak area and the total peak area of other phenolic acids 
(hydroxycinnamic acid conjugates) were used to calculate the percentage of peak area in the chromatogram corresponding to chlorogenic acid.

\subsection{Fruit flesh colour}

Fruit flesh colour parameters were measured with a CR-300 chromameter (Minolta, Osaka, Japan) at the midpoint between the center of the fruit and the pericarp for each of the five fruits that constitute one sample. For small-fruited samples (some wild species and interspecific hybrids) the fruit flesh colour measurement had to be done including the central part of the fruit. The fruit flesh primary colour values obtained were based on the CIELAB 1976 colour coordinates L* ( $0=$ black; 100=white), $\mathrm{a}^{*}$ (positive values=red; negative values=green) and $\mathrm{b}^{*}$ (positive values=yellow; negative values=blue) immediately after the fruit was cut $\left.\mathrm{L}^{*_{0}}, \mathrm{a}^{*_{0}}, \mathrm{~b}^{*_{0}}\right)$. The

distance to pure white colour (DW) was calculated as DW $\left.=\left[\left(100-\mathrm{L}_{0}\right)^{2}+\mathrm{a}^{*}{ }_{0}^{2}+\mathrm{b}^{*}{ }_{0}^{2}\right)\right]^{0.5}($ Prohens, Rodríguez-Burruezo, Raigón, \& Nuez, 2007) and used to determine the DW value just after the cut of the fruit $\left(\mathrm{DW}_{0}\right)$ in order to have a relative measure of the whiteness of the fruit flesh $\left(\mathrm{DW}_{0}\right)$.

\subsection{Fruit flesh browning}

For traits related to browning, the polyphenol oxidase (PPO) activity was determined according to Bellés et al. (2006). Basically, $0.1 \mathrm{~g}$ of lyophilized tissue was homogenized in $4 \mathrm{~mL}$ of $0.1 \mathrm{M}$ sodium phosphate buffer ( $\mathrm{pH} 6.0$ ), and centrifuged at $12,000 \mathrm{rpm}$ for $15 \mathrm{~min}$ at $4{ }^{\circ} \mathrm{C}$. Thereafter, a five-fold dilution of the supernatant was carried out with extraction buffer solution. The control contained $50 \mu \mathrm{L}$ of buffer instead of enzyme extract. The enzymatic reaction was 
followed colourimetrically at $420 \mathrm{~nm}$ in a Nanodrop ND-1000 spectrophotometer (Nanodrop Technologies, Montchain, DE, USA). One unit of enzyme activity was defined as the increase in 0.1 absorbance unit per minute per milligram of dry weight. For determining the liquid extract browning (LEB), we used the protocol described in Plazas et al. (2013). A sample of $0.25 \mathrm{~g}$ of lyophilized tissue was homogenized with $2.5 \mathrm{~mL}$ water and kept for $10 \mathrm{~min}$ at room temperature. Subsequently, $2.5 \mathrm{~mL}$ of a $4 \%$ metaphosphoric solution was added to stop the oxidizing reaction. The control was prepared with $0.25 \mathrm{~g}$ of lyophilized tissue homogenized with $2.5 \mathrm{~mL}$ of $4 \%$ metaphosphoric acid and after $10 \mathrm{~min}, 2.5 \mathrm{~mL}$ of water was added to the solution. After that, the sample and the corresponding control solutions were centrifuged at $8000 \mathrm{rpm}$ for $5 \mathrm{~min}$ before measuring the absorbance at $420 \mathrm{~nm}$ using a ND-1000 spectrophotometer. One unit of LEB was defined as a difference of 0.01 absorbance units between the sample and the control. For the degree of browning (DB) fruit flesh colour parameters $\left(L^{*}, a^{*}, b^{*}\right)$ were measured 10 min after the fruit was cut $\left(\mathrm{L}^{*} 10, \mathrm{a}^{*}{ }_{10}, \mathrm{~b}^{*}{ }_{10}\right)$ at the same position where measurements were taken just after the cut $(0$ min) and $\mathrm{DB}$ was calculated as $\mathrm{DB}=\mathrm{DW}_{10}-\mathrm{DW}_{0}$, where $\mathrm{DW}_{10}$ and $\mathrm{DW}_{0}$ are, respectively $\mathrm{DW}$ values measured at $0 \mathrm{~min}$ and at $10 \mathrm{~min}$ after fruits were opened. The fruit flesh colour difference (CD) after 10 min compared to 0 min was calculated as $\left.\mathrm{CD}=\left[\left(\mathrm{L}^{*} 10-\mathrm{L} * 0\right)^{2}+\left(\mathrm{a}^{*}{ }_{10}-\mathrm{a} *\right)_{0}\right)^{2}\left(\mathrm{~b}^{*} 10-\mathrm{b}^{*}\right)^{2}\right]^{0.5}$ (Prohens, Rodríguez-Burruezo, Raigón, \& Nuez, 2007).

\subsection{Data analysis}

Average values for each accession or interspecific hybrid was used to determine, the mean, range and coefficient of variation $(\mathrm{CV}, \%)$ of each trait for the six groups of cultivated eggplant $(n=6)$, wild relatives of the primary genepool $(n=3)$, wild relatives of the secondary genepool 
( $n=13)$, wild relatives of the tertiary genepool $(n=6)$, interspecific hybrids with primary genepool relatives $(n=18)$ and interspecific hybrids with secondary genepool relatives $(n=27)$. Means were subjected to multifactor analyses of variance (ANOVA) analysis to detect differences among the six groups studied. The significance of differences among group means was evaluated using the Duncan's multiple range test at $P=0.05$. Pearson linear intra-group correlations (to avoid biased results due to differences among group means) based on within-group residuals of accession means was estimated. Mid-parent heterosis $(\mathrm{H})$ value was estimated for all the traits studied using the formula $\mathrm{H}=100 \times[(\mathrm{F} 1-\mathrm{MP}) / \mathrm{MP}]$, where $\mathrm{F}_{1}$ is the interspecific hybrid mean, and MP is the mean of the two parents. All the statistical analyses were performed using the Statgraphics Centurion XVI software (StatPoint Technologies, Warrenton, VA, USA).

\section{Results}

\subsection{Differences among groups}

\subsubsection{Dry matter and phenolics}

The average values for dry matter content among the different groups studied were of more than two-fold, with a range between $10.5 \%$ (in cultivated eggplant) and $21.3 \%$ in wild species or the tertiary genepool (Table 2). For total phenolics content the average differences were almost of two-fold, from $9.8 \mathrm{mg} / \mathrm{g}$ in cultivated eggplant to $18.8 \mathrm{mg} / \mathrm{g}$ in the wild species of the tertiary genepool, while for chlorogenic acid content the range varied from $2.52 \mathrm{mg} / \mathrm{g}$ in the cultivated eggplant to $3.56 \mathrm{mg} / \mathrm{g}$ in the wild species of the primary genepool. When considering the area of 
the chromatogram accounted by chlorogenic acid, the lowest average values were in the wild species of the secondary genepool $(44.3 \%)$, while the highest was in the cultivated eggplant $(79.2 \%)$

Highly significant differences $(\mathrm{P}<0.001)$ were observed among average values of cultivated eggplant, wild relatives and interspecific hybrids for dry matter and phenolics traits (Table 2). For all traits, the largest differences in average values were observed between the cultivated eggplant and hybrids of cultivated eggplant with primary genepool species on one side and the wild secondary and tertiary genepools on the other. In addition, no significant differences were detected between cultivated eggplant and hybrids with the wild primary genepool species or between the wild species of the secondary and tertiary genepool for any of the traits (Table 2). Cultivated eggplant and its hybrids with the primary genepool species had significantly lower contents of dry matter content, phenolics and chlorogenic acid and a higher percentage of chromatogram area corresponding to chlorogenic acid than wild species of the secondary and tertiary genepool (Fig. 1). The wild species from the primary genepool had a significantly higher dry matter, total phenolics and chlorogenic acid contents than the cultivated eggplant, as well as a significantly higher total phenolics content and chlorogenic acid content than the hybrids with the primary genepool species. The hybrids with the secondary genepool species had values for dry matter, total phenolics, and chlorogenic acid content not significantly different to the cultivated species (Table 2).

\subsubsection{Fruit flesh colour}


An important range of variation was observed for the $\mathrm{L}^{*}{ }_{0}$ parameter (for a scale for $\mathrm{L}_{0}$ going from 0 to 100), with mean values among the different groups with values ranging from 46.1 for the tertiary genepool wild species to 82.7 for the cultivated eggplant (Table 3). However, for the $\mathrm{a}^{*_{0}}$ parameter, all the group averages were similar, while for $\mathrm{b}_{0}$ the differences ranged from 13.7 in the hybrids with the primary genepool species to 20.6 in the wild species of the secondary genepool (Table 3). Finally, for the $\mathrm{DW}_{0}$ value the differences were also important, with a minimum average value of 23.0 in the cultivated eggplant to 57.6 in the wild species of the tertiary genepool.

Highly significant differences $(\mathrm{P}<0.001)$ were observed among average values of cultivated eggplant, wild relatives and interspecific hybrids for all fruit flesh colour traits except for $\mathrm{a}_{0}$ (Table 3 ). The cultivated eggplant group and the hybrids with the wild primary genepool had the whitest flesh. These two last groups differed significantly for $\mathrm{L}_{0}, \mathrm{~b}_{0}{ }_{0}$, and $\mathrm{DW}_{0}$ from the wild species of the secondary and tertiary genepools, and also differed from the wild species of the primary genepool and hybrids with the secondary genepool for $\mathrm{L}_{0}$ and $\mathrm{DW}_{0}$, and from the hybrids with the secondary genepool for $\mathrm{b}_{0}{ }_{0}$ (Table 3$)$.

\subsubsection{Fruit flesh browning}

The average value differences for PPO activity among the different groups studied were of more than 8.7-fold (Table 3). For LEB, DB, and CD the relative differences were much lower, with differences of around 2-fold (Table 4). Highly significant differences $(\mathrm{P}<0.001)$ were observed among average values of cultivated eggplant, wild relatives and interspecific hybrids for all flesh browning related traits. For PPO activity several significant differences were observed 
among groups, with the cultivated eggplant and hybrids with primary genepool species displaying values significantly lower than those of the wild species of the secondary and tertiary genepools. Also, the wild species of the primary genepool and the hybrids with the secondary genepool presented values significantly lower than those of the tertiary genepool (Table 3). For LEB, the only significant differences detected were among average group values were between the cultivated eggplant on one side (with lower values) and the tertiary genepool and hybrids with secondary genepool species (with higher values). For the DB, the only significant differences were among cultivated eggplant, with lower values, and the wild species of the primary genepool and hybrids with secondary genepool species, with higher values, on the other. Finally, for CD, the only significant differences were between the cultivated eggplant and hybrids with primary genepool species on one side and hybrids with secondary genepool on the other (Table 3).

\subsection{Differences within groups}

\subsubsection{Dry matter and phenolics}

A large range of variation was found for accession average values for most traits within each of the groups considered, in some cases with differences of several-fold among accession values (Table 2). In this respect, the largest relative difference was observed for the percentage of chromatogram peak area corresponding to chlorogenic acid, with differences of almost 4.5 -fold in the wild species of the tertiary genepool. For the rest of groups also large differences were observed, although in some cases, like dry matter content, phenolics and chlorogenic acid in the wild species of the primary genepool the range of variation was generally low. Also, wide variation 
was observed in the interspecific hybrids and the values of the hybrids exceeded those of the accessions of the cultivated species with highest values, except for the percentage of the area under the curve accounted by chlorogenic acid. In any case, the wide variation observed within most of the groups resulted in an overlap of the ranges of variation in most cases (Table 2).

The values for the coefficient of variation were very variable depending on the group and trait considered (Table 2). It is remarkable that for all traits the wild species of the secondary and tertiary genepools displayed larger values of the coefficient of variation than the cultivated species, which nonetheless presented values for the coefficient of variation of up to $23.4 \%$ for the total phenolics. The interspecific hybrids presented a value for the coefficient of variation values in some cases similar to those of the cultivated species and in other cases similar to some of the wild species groups (Table 2).

\subsubsection{Fruit flesh colour}

Within each of the groups considered variation was found among accessions for the traits, studied, although there were differences in the range both among groups and among traits (Table 3). For $\mathrm{L}_{0}$ the largest variation was observed in the hybrids with secondary genepool species with a difference among accessions of 33.3 units, while the lowest was for cultivated eggplant with a difference among accessions of 7.0 units. The range of variation of cultivated eggplant did not overlap with those of any of the other groups, except with the hybrids with the primary genepool species. For $\mathrm{a}_{0}{ }_{0}$ and $\mathrm{b}_{0}{ }_{0}$ the ranges of variation were considerably lower (Table 3 ). In all cases, the ranges of variation for $\mathrm{a}_{0}$ for the different groups overlapped. Similarly, for $\mathrm{b}^{*}$, the ranges of variation overlapped in all groups except between the hybrids of the primary genepool species on 
one side (with lower values) and the wild species of the secondary genepool on the other (with higher values). For $\mathrm{DW}_{0}$, the greatest range of variation was found for the hybrids with secondary genepool species, and the lowest was found among wild species of the tertiary genepool species. The ranges of variation for $\mathrm{DW}_{0}$ of the cultivated species, wild species of the primary genepool, and hybrids with primary genepool species overlapped, but these three groups did not overlap with the wild species of the secondary or tertiary genepool species, which had larger $\mathrm{DW}_{0}$ values than the former (Table 3). The hybrids with secondary genepool species overlapped in the range of variation with the rest of groups, except with the cultivated species, which had lower values for $\mathrm{DW}_{0}$. The values of coefficient of variation for $\mathrm{a}_{0}$ were much larger than for the rest of traits (Table 3), due to the fact that values of $\mathrm{a}^{*_{0}}$ are close to 0.

\subsubsection{Fruit flesh browning}

A considerable variation was found within each group studied for the average values for the fruit flesh browning related traits studied (Table 3). The largest differences were found for the PPO activity, with up to 56-fold differences in the case of hybrids of secondary genepool and almost 26-fold for the secondary genepool species. Even for the cultivated eggplant, there were differences between 1.96-fold (for CD) to 7.0-fold (LEB) for the all the traits studied (Table 3). In contrast, the differences were lowest in the case of primary genepool species. For rest of the groups considered also large differences were observed (Table 3). When considering each of the traits evaluated, the ranges of variation of the six groups considered overlapped, except for PPO activity between the cultivated eggplant (lower values) and the wild tertiary genepool species (higher 
values) and for DB and CD between the cultivated eggplant (lower values) and the wild species of the primary genepool (higher values) (Table 3).

The coefficient of variation was highly variable, ranging from $14.1 \%$ for the LEB in the primary genepool species to $121.1 \%$ for PPO activity in the secondary genepool species (Table 3 ). In most of the cases, the secondary and tertiary genepool species along with interspecific hybrids of secondary genepool displayed higher values for the coefficient of variation than rest of the groups, although in some cases, like LEB relatively high values were also observed in the cultivated eggplant (Table 3).

\subsection{Correlations among traits}

A total of 17 pairwise correlation within-group residuals of accessions means were found to be significant $(\mathrm{P}<0.05)$ (Table 4). Two of these correlations presented very high absolute values (above 0.75 ), and corresponded to positive correlations between $\mathrm{L}^{*_{0}}$ and $\mathrm{DW}_{0}$, and between $\mathrm{DB}$ and CD (Table 4). Also, the content of total phenolics presented a moderate positive correlation with the content in chlorogenic acid, but these two traits were not correlated with browning traits. The content of chlorogenic acid was correlated with the total area under the curve, but not with browning traits (Table 4). However, the percentage of chlorogenic acid area in the chromatogram was positively correlated with $\mathrm{a}_{0}$ and negatively correlated with browning traits (LEB, DB, and CD). Also, $\mathrm{a}_{0}{ }_{0}$ was negatively correlated with PPO activity, LEB, and CD, while $\mathrm{b}_{0}{ }_{0}$ was positively correlated with DB and CD. Finally, PPO activity was found to be positively correlated with both DB and CD, and LEB was also positively correlated to both DB and CD (Table 4). 
When considering the relationship between the degree of browning in the different materials studied with the different traits related to concentration in phenolic compounds (Fig. 2), it can be observed that there are several accessions of the secondary genepool and hybrids of eggplant with this secondary genepool species that present low values for browning and high levels for total phenolics, and chlorogenic acid content (Fig. 2). Also, it can be observed that many of the hybrids with the primary genepool species have similar values for browning and for the rest of traits than the cultivated eggplant, although one of them presents low browning and high content in chlorogenic acid. Remarkably, some wild species and interspecific hybrids displayed a high DB but values for the phenolics content traits similar to those of cultivated eggplant (Fig. 2).

\subsection{Heterosis}

Different species belonging to different gene pools performed differently regarding heterosis (Table 5). Interspecific hybrids with cultivated eggplant primary gene pool species $S$. insanum displayed negative or non-significant heterosis for almost all the characters studied except for $\mathrm{L}_{0}{ }_{0}$ and PPO activity, in which heterosis values were positive. The highest absolute values for heterosis in the hybrids with S. insanum were for phenolics content $(-23.3 \%)$ and the content of chlorogenic acid (-21.8\%). Regarding interspecific hybrids involving the secondary gene pool species, the general trend was opposite, with positive heterosis for most traits and few traits displaying negative heterosis, like the percentage of area under the curve corresponding to chlorogenic acid in hybrids with all species. Also, dry matter content and L0 presented negative values for heterosis in hybrids with several wild species. For the rest of traits heterosis was generally positive or non-significant (Table 5). Most of the interspecific hybrids with secondary 
genepool species demonstrated heterosis for total phenolics content with values of up to $73.9 \%$ in hybrids involving S.tomentosum. Regarding chlorogenic acid content, all secondary gene pool interspecific hybrids presented positive heterosis with highest values in $S$. anguivi, with an heterosis of $76.5 \%$. Amazingly, in general, high positive values for heterosis, in some cases above $100 \%$, were found for PPO activity and browning related traits (LEB, DB and CD) in interspecific hybrids with secondary genepool species (Table 5).

\section{Discussion}

Eggplant has high levels of phenolics, particularly phenolic acids (Stommel \& Whitaker, 2003; Mennella et al., 2012; Prohens et al., 2013; Docimo et al., 2016a) and the development of varieties with an enhanced content of phenolic acids is a current breeding objective (Plazas et al., 2013a; Kaushik et al., 2015). However, increases in phenolic acids content can result in a greater degree of fruit flesh browning due to the phenolic oxidation mediated by PPOs (Prohens, Rodríguez-Burruezo, Raigón, \& Nuez, 2007; Plazas et al., 2013b; Uchida, Tomita, Takemori, \& Takamura, 2017), which reduces the visual quality of the fruit both for the fresh market and for the processing industry (Mishra, Gautam, \& Sharma, 2012).

Some wild relatives of eggplant have been reported as having significantly higher contents (of several-fold) in phenolic acids than cultivated eggplant (Stommel \& Whitaker, 2003; Ma, Whitaker, \& Kennelly, 2010; Mennella et al., 2012; Prohens et al., 2013; Kaur, Nagal, Nishad, Kumar, \& Sarika, 2014; Plazas et al., 2014; Meyer et al., 2015). Therefore, eggplant wild relatives may represent new sources of variation for increasing the bioactive properties of cultivated eggplant (Plazas et al., 2013a; Prohens et al., 2013). Our results reveal that, as occurs for 
morphological traits (Kaushik, Prohens, Vilanova, Gramazio, \& Plazas, 2016) and molecular markers (Vorontsova, Stern, Bohs, \& Knapp, 2013), there is a great diversity among wild species for the composition and fruit flesh colour and browning traits studied. The generally higher contents in total phenolics in the wild species indicate that there is large potential among wild relatives for breeding for bioactive properties of eggplant, as the measurement of total phenolics by the Folin-Ciocalteu method is also a measure of reducing capacity (Singleton \& Rossi, 1965; Plazas et al., 2014) and in eggplant materials is generally correlated with other measures of bioactivity like antioxidant activity estimated with several methods like the cupric ion antioxidant reducing capacity (CUPRAC), 2,2-diphenyl-1-picrylhydrazyl (DPPH) antioxidant activity, ferric reducing antioxidant power (FRAP), or Trolox equivalent antioxidant capacity (TEAC) (Kaur, Nagal, Nishad, Kumar, \& Sarika, 2014). In this way, some of the wild species had contents in total phenolics and chlorogenic acid contents several fold higher than those of the cultivated accessions. In this respect, Prohens et al. (2013) found individuals in the first backcross towards the cultivated eggplant of an interspecific hybrid between the latter and $S$. incanum with considerably higher levels of phenolic acids that the cultivated recurrent eggplant parent. On the other hand, Mennella et al. (2010) did not find increased contents in phenolic acids in introgression lines of $S$. sodomaeum (=S. linnaeanum); however, these lines had been selected for tolerance for Verticillium wilt and not for phenolics acid content.

In eggplant, chlorogenic acid is the predominant phenolic acid in the fruit flesh (Stommel \& Whitaker, 2003; Mennella et al., 2012; Prohens et al., 2013) and the same occurs in the primary genepool species S. insanum, which is its wild ancestor (Knapp, Vorontsova, \& Prohens, 2013). A similar result was found by Meyer et al. (2015). Amazingly, in the wild relatives of the secondary and tertiary genepool, the percentage of the chromatogram peak accounted by chlorogenic acid 
was on average much lower, indicating that other derivatives of hydroxycinnamic acid represented an important part of the phenolic acids content. In other studies, Plazas et al. (2014) found that in the secondary genepool species $S$. dasyphyllum, chlorogenic acid peak only accounted for around $50 \%$ of the HPLC chromatogram area, while Meyer et al. (2015) found that in the secondary genepool species $S$. violaceum chlorogenic acid was a minor constituent in the phenolic acids fraction. On the other hand, in secondary genepool species S. incanum (Prohens et al., 2013) and S. linnaeanum (Meyer et al., 2015) it has been found that chlorogenic acid was the most important phenolic acid. Some of these other phenolic acids and their derivatives also have important bioactive properties (Heleno, Martins, Queiroz, \& Ferreira, 2015), and therefore may also be of interest for introgression in eggplant.

A white fruit flesh colour is desirable for most eggplant markets (Daunay \& Hazra, 2012), and the cultivated eggplant had much higher luminosity $\left(\mathrm{L}^{*}\right)$ and therefore a lower distance to pure white $\left(\mathrm{DW}_{0}\right)$ than the wild species. Wild species of Solanum crops usually have chlorophylls and carotenoids in the fruit flesh (Acosta-Quezada et al., 2015; Herraiz et al., 2016), which as in the case of eggplant result in a less white flesh. In this case, the primary genepool species presented better characteristics, with a fruit flesh colour closer to pure white than those of secondary and tertiary genepool species. Regarding browning traits, wild relatives generally had much higher PPO activity than the cultivated species and had higher fruit flesh browning. The higher PPO activity in wild eggplant relatives compared to cultivated species may be related to the fact that PPOs are involved in plant defence (Shetty, Chandrashekar, \& Venkatesh, 2011), and therefore may be enhanced in the wild species.

The interspecific hybrids with the primary genepool species $S$. insanum are morphologically intermediate between the two parents, while those with secondary genepool 
species are more similar to the wild species (Kaushik, Prohens, Vilanova, Gramazio, \& Plazas, 2016). A very similar result has been obtained with the traits measured here, with interspecific hybrids with $S$. insanum more similar to cultivated eggplant in phenolic composition, fruit flesh and browning characteristics, while interspecific hybrids with secondary genepool species were more similar to the wild parents for these characteristics. This seems to indicate that, generally, for secondary wild species there is dominance of the alleles of the wild species over those of the cultivated eggplant, and therefore are heterotic, while those of $S$. insanum have intermediate dominance. This suggests that secondary and tertiary genepool species may be of greater interest than the closely related $S$. insanum to improve the content of phenolics in eggplant, but not for the fruit flesh colour and browning traits. However, studies with segregating generations will be helpful to confirm the inheritance mode from these secondary genepool species.

Association between target traits is important for breeding. In this respect, the high values for the correlations between the luminosity and high degree of whiteness and also between the degree of browning and colour difference were expected (Prohens, Rodríguez-Burruezo, Raigón, \& Nuez, 2007), as they represent different measures of the same phenomenon (fruit flesh colour and browning, respectively). Similarly, the correlation between total phenolics and chlorogenic acid content is a common phenomenon in eggplant (Plazas et al., 2013b), reflecting that chlorogenic acid has a major role in the reducing capacity of eggplant fruits. However, the values obtained by us here for the correlation between these two traits has been lower than in this latter study, probably due to the fact that we are dealing with materials that are genetically very different (wild species) to the ones used by these authors (local Spanish landraces). Most interestingly, no significant correlations have been observed between total phenolics content or chlorogenic acid content with any of the fruit flesh colour or browning traits, which suggests that these traits may 
be independent. In fact, some of the interspecific hybrids had a high content in total phenolics and chlorogenic acid content and limited browning. In this respect, genetic and QTL mapping studies reveal that QTLs for chlorogenic acid content as well as the genes involved in the accumulation of chlorogenic acid pathway are not linked to the PPO genes cluster (Gramazio et al., 2014; Docimo et al., 2016a). This is important, as in our materials PPO activity has shown to have a positive correlation with browning traits, which indicates that by selecting for low PPO activity it is possible to develop materials with reduced browning. The role of other enzymes, like peroxidases, in eggplant fruit browning should be investigated, although several researches suggest that they might play a minor role compared to PPOs (Concellón et al., 2004; Mishra, Gautam, \& Sharma, 2013; Zaro et al., 2014; Uchida, Tomita, Takemori, \& Takamura, 2017).

Overall, our results reveal that wild relatives of eggplant are highly variable for traits related to phenolics content, and fruit flesh colour and browning and represent a source of variation of interest, in particular in the case of wild species from the secondary and tertiary genepools, for improving the content in phenolics of cultivated eggplant. However, for the fruit flesh colour and browning traits, the characteristics present in the wild species are detrimental. In addition, the lack of correlation between phenolics content traits on one side and fruit flesh colour and browning on the other suggest that the wild relatives can make an effective contribution to the improvement of the bioactive properties of eggplant, while keeping a white fruit colour and low browning.

\section{Conflict of interest}

No conflict of interest declared. 


\section{Abbreviations}

ANOVA: analysis of variance

BHT: 2,3-tert-Butyl-4-hydroxyanisole

CD: colour difference

CUPRAC: cupric ion antioxidant reducing capacity

$\mathrm{CV}$ : coefficient of variation

DB: degree of browning

DPPH: 2,2-diphenyl-1-picrylhydrazyl

DW: distance to pure white colour

FRAP: ferric reducing antioxidant power

H: mid-parent heterosis

HPLC: high-performance liquid chromatography

LEB: liquid extract browning

MP: mean of the two parents

PPO: polyphenol oxidase

PTFE: polytetrafluoroethylene

TEAC: Trolox equivalent antioxidant capacity

\section{Acknowledgements}

This work has been funded in part by the initiative "Adapting Agriculture to Climate Change: Collecting, Protecting and Preparing Crop Wild Relatives", which is supported by the 
Government of Norway. This project is managed by the Global Crop Diversity Trust with the Millennium Seed Bank of the Royal Botanic Gardens, Kew and implemented in partnership with national and international gene banks and plant breeding institutes around the world. For further information see the project website: http://www.cwrdiversity.org/. Funding has also been received from the European Union's Horizon 2020 Research and Innovation Programme under grant agreement No 677379 (G2P-SOL project: Linking genetic resources, genomes and phenotypes of Solanaceous crops) and from Spanish Ministerio de Economía y Competitividad and Fondo Europeo de Desarrollo Regional (grant AGL2015-64755-R from MINECO/FEDER). Prashant Kaushik is grateful to ICAR for a pre-doctoral grant. Pietro Gramazio is grateful to Universitat Politècnica de València for a pre-doctoral (Programa FPI de la UPV-Subprograma 1/2013 call) contract.

\section{References}

Acosta-Quezada, P. G., Raigón, M. D., Riofrío-Cuenca, T., García-Martínez, M. D., Plazas, M., Burneo, J. I., Figueroa, J. G., Vilanova, S., \& Prohens, J. (2015). Diversity for chemical composition in a collection of different varietal types of tree tomato (Solanum betaceum Cav.), an Andean exotic fruit. Food Chemistry, 169, 327-335.

Bellés, J. M., Garro, R., Pallás, V., Fayos, J., Rodrigo, I., \& Conejero, V. (2006). Accumulation of gentisic acid as associated with systemic infections but not with the hypersensitive response in plant-pathogen interactions. Planta, 223, 500-511.

Daunay, M. C., \& Hazra, P. (2012). Eggplant. In K. Peter, \& P. Hazra (Eds.), Handbook of vegetables (pp. 257-322). Houston, TX: Studium Press. 
Di Guardo, M., Tadiello, A., Farneti, B., Lorenz, G., Masuero, D., Vrhovsek, U., Costa, G., Velasco, R., \& Costa, F. (2013). A multidisciplinary approach providing new insight into fruit flesh browning physiology in apples (Malus x domestica Borkh.). PLOS ONE, 8, e78004.

Docimo, T., Francese, G., Ruggiero, A., Batelli, G., Palma, M., Bassolino, L., Toppino, L., Rotino, G., Mennella, G., \& Tucci, M. (2016a). Phenylpropanoids accumulation in eggplant fruit: characterization of biosynthetic genes and regulation by a MYB transcription factor. Frontiers in Plant Science, 6, 1233.

Docimo, T., Francese, G., De Palma, M., Mennella, D., Toppino, L., Lo Scalzo, R., Mennella, G., \& Tucci, M. (2016b). Insights in the fruit flesh browning mechanisms in Solanum melongena genetic lines with opposite postcut behavior. Journal of Agricultural and Food Chemistry, 64, 4675-4685.

Gramazio, P., Prohens, J., Plazas, M., Andújar, I., Herraiz, F., Castillo, E., Knapp, S., Meyer, R., \& Vilanova, S. (2014). Location of chlorogenic acid biosynthesis pathway and polyphenol oxidase genes in a new interspecific anchored linkage map of eggplant. BMC Plant Biology, 14, 350 .

Heleno, S. A., Martins, A., Queiroz, M. J. R. P., \& Ferreira, I. C. F. R. (2015). Bioactivity of phenolic acids: metabolites versus parent compounds: a review. Food Chemistry, 173, 501513.

Herraiz, F.J., Raigón, M.D., Vilanova, S., García-Martínez, M.D., Gramazio, P., Plazas, M., Rodríguez-Burruezo, A., \& Prohens, J. (2016). Fruit composition diversity in land races and modern pepino (Solanum muricatum) varieties and wild related species. Food Chemistry, 203, 49-58. 
Kaur, C., Nagal, S., Nishad, J., \& Sarika (2014). Evaluating eggplant (Solanum melongena L.) genotypes for bioactive properties: A chemometric approach. Food Research International, 60, 205-211.

Kaushik, P., Andújar, I., Vilanova, S., Plazas, M., Gramazio, P., Herraiz, F. J., Brar, N. S., \& Prohens, J. (2015). Breeding vegetables with increased content in bioactive phenolic acids. Molecules, 20, 18464-18481.

Kaushik, P., Prohens, J., Vilanova, S., Gramazio, P., \& Plazas, M. (2016). Phenotyping of eggplant wild relatives and interspecific hybrids with conventional and phenomics descriptors provides insight for their potential utilization in breeding. Frontiers in Plant Science, 7 , 677.

Knapp, S., Vorontsova, M., \& Prohens, J. (2013). Wild relatives of the eggplant (Solanum melongena L.: Solanaceae): new understanding of species names in a complex group. PLOS ONE, 8, e57039.

Kouassi, B., Prohens, J., Gramazio, P., Kouassi, A. B., Vilanova, S., Galán-Ávila, A., Herraiz, F.J., Kouassi, A., Seguí-Simarro, J. M., \& Plazas, M. (2016). Development of backcross generations and new interspecific hybrid combinations for introgression breeding in eggplant (Solanum melongena). Scientia Horticulturae, 213, 199-207.

Ma, C. H., Whitaker, B. D., \& Kennelly, E. J. (2010). New 5-O-caffeoylquinic acid derivatives in fruit of the wild eggplant relative Solanum viarum. Journal of Agricultural and Food Chemistry, 58, 11036-11042.

Mennella, G., Rotino, G. L., Fibiani, M., D’Alessandro, A., Francese, G., Toppino, L., Cavallanti, F., Acciarri, N., \& Scalzo, R. (2010). Characterization of health-related compounds in 
eggplant (Solanum melongena L.) lines derived from introgression of allied species. Journal of Agricultural and Food Chemistry, 58, 7597-7603.

Mennella, G., Lo Scalzo, R., Fibiani, M., D’Alessandro, A., Francese, G., Toppino, L., Acciarri, N., de Almeida, A. E., \& Rotino, G. L. (2012). Chemical and bioactive quality traits during fruit ripening in eggplant (S. melongena $\mathrm{L}$.) and allied species. Journal of Agricultural and Food Chemistry, 60, 11821-11831.

Meyer, R. S., Whitaker, B. D., Little, D. P., Wu, S. B. B., Kennelly, E. J., Long, C. L. L., \& Litt, A. (2015). Parallel reductions in phenolic constituents resulting from the domestication of eggplant. Phytochemistry, 115, 194-206.

Mishra, B. B., Gautam, S., \& Sharma, A. (2012). Browning of fresh-cut eggplant: Impact of cutting and storage. Postharvest Biology and Technology 67, 44-51.

Mishra, B. B., Gautam, S., \& Sharma, A. (2013). Free phenolics and polyphenol oxidase (PPO): the factors affecting post-cut browning in eggplant (Solanum melongena). Food Chemistry $139,105-114$.

Nayak, B., Liu, R. H., \& Tang, J. (2015). Effect of processing on phenolic antioxidants of fruits, vegetables, and grains--a review. Critical Reviews in Food Science and Nutrition, 55, 887919.

Plazas, M., Andújar, I., Vilanova, S., Hurtado, M., Gramazio, P., Herráiz, F. J, \& Prohens, J. (2013a). Breeding for chlorogenic acid content in eggplant: interest and prospects. Notulae Botanicae Horti Agrobotanici Cluj-Napoca, 41, 26-35.

Plazas, M., Vilanova, S., Gramazio, P., Rodríguez-Burruezo, A., Fita, A., Herraiz, F. J., Bellés, J. M., \& Prohens, J. (2013b). Diversity and relationships in key traits for functional and apparent quality in a collection of eggplant: fruit phenolics content, antioxidant activity, 
polyphenol oxidase activity, and browning. Journal of Agricultural and Food Chemistry, $61,8871-8879$.

Plazas, M., Prohens, J., Cuñat, A. N., Vilanova, S., Gramazio, P., Herraiz, F.J., \& Andújar, I. (2014). Reducing capacity, chlorogenic acid content and biological activity in a collection of scarlet (Solanum aethiopicum) and gboma (S. macrocarpon) eggplants. International Journal of Molecular Sciences, 15, 17221-17241.

Plazas, M., Vilanova, S., Gramazio, P., Rodríguez-Burruezo, A., Fita, A., Herraiz, F. J., Ranil, R., Fonseka, R., Niran, L., Fonseka, H., Kouassi, B., Kouassi, A., Kouassi, A., \& Prohens, J. (2016). Interspecific hybridization between eggplant and wild relatives from different genepools. Journal of the American Society for Horticultural Science, 141, 34-44.

Prohens, J., Rodríguez-Burruezo, A., Raigón, M. D., \& Nuez, F. (2007). Total phenolic concentration and browning susceptibility in a collection of different varietal types and hybrids of eggplant: Implications for breeding for higher nutritional quality and reduced browning. Journal of the American Society for Horticultural Science, 132, 638-646.

Prohens, J., Whitaker, B. D., Plazas, M., Vilanova, S., Hurtado, M., Blasco, M., Gramazio, P., \& Stommel J. R. (2013). Genetic diversity in morphological characters and phenolic acids content resulting from an interspecific cross between eggplant, Solanum melongena, and its wild ancestor (S. incanum). Annals of Applied Biology, 162, 242-257.

Rotino, G. L., Salta, T., \& Toppino, L. (2014). Eggplant. In A. Pratap, \& J. Kumar (Eds.), Alien gene transfer in crop plants, vol. 2 (pp. 381-409). New York: Springer.

Singleton, V. L., \& Rossi, J. A. (1965). Colourimetry of total phenolics with phosphomolybdic phosphotungstic reagents. American Journal of Enology and Viticulture, 16, 144-158. 
Shetty, S., Chandrashekar, A., \& Venkatesh, Y. (2011). Eggplant polyphenol oxidase multigene family: Cloning, phylogeny, expression analyses and immunolocalization in response to wounding. Phytochemistry, 72, 2275-2287.

Stommel, J., \& Whitaker, B. (2003). Phenolic acid content and composition of eggplant fruit in a germplasm core subset. Journal of the American Society for Horticultural Science, 128, 704-710.

Syfert, M. M., Castañeda-Álvarez, N. P., Khoury, C. K., Särkinen, T., Sosa, C. C., Achicanoy, H. A., Bernau, V., Prohens, J., Daunay, M. C., \& Knapp, S. (2016). Crop wild relatives of the brinjal eggplant (Solanum melongena): Poorly represented in genebanks and many species at risk of extinction. American Journal of Botany, 103, 635-651.

Uchida, K., Tomita, H., Takemori, T., \& Takamura, H. (2017). Effects of grilling on total polyphenol content and antioxidant capacity of eggplant (Solanum melongena L.). Journal of Food Science, 82, 202-207.

Urbany, C., Stich, B., Schmidt, L., Simon, L., Berding, H., Junghans, H., Niehoff, K. H., Braun, A., Tacke, E., Hofferbert, H. R., Lubeck, J., Strahwald, J., \& Gebhardt, C. (2011). Association genetics in Solanum tuberosum provides new insights into potato tuber bruising and enzymatic tissue discoloration. BMC Genomics, 12, 7.

Vorontsova, M., Stern, S., Bohs, L., \& Knapp, S. (2013). African spiny Solanum (subgenus Leptostemonum, Solanaceae): a thorny phylogenetic tangle. Botanical Journal of the Linnean Society, 173, 176-193. 


\section{Table 1}

Accessions of cultivated eggplant (Solanum melongena) and wild relatives of the primary secondary and tertiary genepools, and interspecific hybrids between cultivated eggplant and wild relatives of primary and secondary genepool used for fruit dry matter and phenolics composition, flesh colour and browning related traits. For the interspecific hybrids, the first and second parents included in the hybrid code correspond to the female and male, respectively.

\begin{tabular}{|c|c|c|c|c|c|c|c|c|c|}
\hline \multirow{2}{*}{ Species } & \multirow{2}{*}{ Accession } & \multirow{2}{*}{$\begin{array}{l}\text { Germplasm } \\
\text { collection code }\end{array}$} & \multirow{2}{*}{$\begin{array}{l}\text { Country of } \\
\text { origin }\end{array}$} & \multicolumn{6}{|c|}{ Interspecific hybrids with $S$. melongena accessions } \\
\hline & & & & MEL1 & MEL2 & MEL3 & MEL4 & MEL5 & MEL6 \\
\hline \multicolumn{10}{|c|}{ Cultivated eggplant } \\
\hline \multirow[t]{6}{*}{ S. melongena $L$. } & MEL1 & BBS-118/B & Ivory Coast & & & & & & \\
\hline & MEL2 & BBS-146 & Ivory Coast & & & & & & \\
\hline & MEL3 & BBS-175 & Ivory Coast & & & & & & \\
\hline & MEL4 & 7145 & Sri Lanka & & & & & & \\
\hline & MEL5 & 8104 & Sri Lanka & & & & & & \\
\hline & MEL6 & Ampara & Sri Lanka & & & & & & \\
\hline \multicolumn{10}{|c|}{ Wild primary genepool (GP1) } \\
\hline \multirow[t]{3}{*}{ S. insanum L. } & INS1 & SLKINS-1 & Sri Lanka & MEL1×INS1 & MEL2×INS1 & MEL3×INS1 & MEL4×INS1 & INS1×MEL5 & MEL6 $\times$ INS1 \\
\hline & INS2 & SLKINS-1 & Sri Lanka & MEL1×INS2 & MEL2×INS2 & MEL3×INS2 & MEL4×INS2 & MEL5 $\times$ INS2 & MEL6×INS2 \\
\hline & INS3 & MM498 & Japan & INS3×MEL1 & INS3×MEL2 & INS3×MEL3 & INS3×MEL4 & MEL5×INS3 & INS3×MEL6 \\
\hline
\end{tabular}

Wild secondary genepool (GP2) 


\begin{tabular}{|c|c|c|c|c|c|c|c|c|c|}
\hline \multirow[t]{2}{*}{ S. anguivi Lam. } & ANG1 & BBS119 & Ivory Coast & & MEL2×ANG1 & MEL3×ANG1 & MEL4×ANG1 & \multicolumn{2}{|l|}{ MEL5×ANG1 } \\
\hline & ANG2 & $\mathrm{BBS} 125 / \mathrm{B}$ & Ivory Coast & MEL1×ANG2 & MEL2×ANG2 & ANG2×MEL3 & ANG $2 \times$ MEL4 & MEL5×ANG2 & ANG2×MEL6 \\
\hline S. campylacanthum & ¿ CAM6 & MM700 & Kenya & & & & & & \\
\hline Hochst. ex A. Rich. & CAM8 & MM1426 & Tanzania & & & & & & \\
\hline S. dasyphyllum & DAS1 & MM1153 & Uganda & MEL1×DAS1 & & & & & \\
\hline \multicolumn{10}{|l|}{ Schumach. \& } \\
\hline \multicolumn{10}{|l|}{ Thonn. } \\
\hline S. incanum $\mathrm{L}$. & INC1 & MM664 & Israel & INC1×MEL1 & & MEL3×INC1 & & MEL5×INC1 & MEL6×INC1 \\
\hline S. lichtensteinii & LIC1 & MM674 & South Africa & MEL1×LIC1 & & & & MEL5×LIC1 & MEL6×LIC1 \\
\hline Willd. & LIC2 & MM677 & Iran & MEL1×LIC2 & & MEL3×LIC2 & MEL4×LIC2 & & \\
\hline S. linnaeanum & LIN1 & JPT0028 & Spain & & & & & & LIN1×MEL6 \\
\hline Hepper \& P.-M. L. & LIN3 & MM195 & Tunisia & & & & & & \\
\hline \multicolumn{10}{|l|}{ Jaeger } \\
\hline S. pyracanthos Lam. & I.PYR1 & SOLN-66 & Unknown & & & & & & \\
\hline S. tomentosum $\mathrm{L}$. & TOM1 & MM992 & South Africa & & MEL2×TOM1 & TOM1×MEL3 & & & \\
\hline S. violaceum & VIO1 & SLKVIL-1 & Sri Lanka & & & & & & \\
\hline \multicolumn{10}{|l|}{ Ortega } \\
\hline \multicolumn{10}{|c|}{ Wild tertiary genepool (GP3) } \\
\hline S. elaeagnifolium & ELE1 & MM1627 & Senegal & & & & & & \\
\hline Cav. & ELE2 & Agora & Greece & & & & & & \\
\hline
\end{tabular}




$\begin{array}{llll}\text { S. sisymbriifolium } & \text { SIS1 } & \text { SOLN-78 } & \text { Unknown } \\ \text { Lam. } & & & \\ & \text { SIS2 } & 1180 & \text { Unknown } \\ & & & \\ \text { S. torvum Sw. } & \text { TOR2 } & \text { SLKTOR-2 } & \text { Sri Lanka } \\ & \text { TOR3 } & 55953 & \text { Unknown }\end{array}$




\section{Table 2}

Mean, range (between brackets), and coefficient of variation $(\mathrm{CV} ; \%)$ for dry matter, total phenolics; chlorogenic acid content; percentage area \% of chlorogenic acid content under the HPLC chromatogram curve in accessions of cultivated eggplant ( $S$. melongena; $\mathrm{n}=6$ ), wild relatives of the primary $(n=3)$, secondary $(n=18)$ and tertiary $(n=6)$ genepools and interspecific hybrids between cultivated eggplant and wild relatives from the primary genepool $(n=18)$ and secondary genepool $(n=24)$ and significance of mean differences among the six groups.

\begin{tabular}{lcccc}
\hline Accessions & Dry matter $(\%)$ & $\begin{array}{c}\text { Total phenolics } \\
(\mathrm{mg} / \mathrm{g})\end{array}$ & $\begin{array}{c}\text { Chlorogenic acid } \\
\text { content }(\mathrm{mg} / \mathrm{g})\end{array}$ & $\begin{array}{c}\text { Chlorogenic acid } \\
\text { peak area }(\%)\end{array}$ \\
\hline Cultivated eggplant & $10.5 \mathrm{a}$ & $9.8 \mathrm{a}$ & $2.52 \mathrm{ab}$ & $79.2 \mathrm{~b}$ \\
Mean & $(6.8-13.6)$ & $(6.2-12.2)$ & $(1.43-2.93)$ & $(67.4-86.8)$ \\
Range & 21.8 & 23.4 & 21.6 & 8.9 \\
CV & & & & \\
Wild primary genepool (GP1) & $16.0 \mathrm{bc}$ & $16.3 \mathrm{~b}$ & $3.56 \mathrm{c}$ & $73.0 \mathrm{~b}$ \\
Mean & $(14.6-17.7)$ & $(14.6-17.3)$ & $(3.00-3.97)$ & $(65.1-79.2)$ \\
Range & 9.8 & 9.0 & 14.0 & 9.9 \\
CV & & & & \\
\end{tabular}

Wild secondary genepool (GP2)

$\begin{array}{lcccc}\text { Mean } & 19.7 \mathrm{~cd} & 18.4 \mathrm{~b} & 3.25 \mathrm{bc} & 44.3 \mathrm{a} \\ \text { Range } & (11.8-29.5) & (9.6-27.6) & (1.25-4.71) & (25.3-65.0) \\ \text { CV } & 28.7 & 33.6 & 30.4 & 28.1\end{array}$

Wild tertiary genepool (GP3)
Mean
$21.3 \mathrm{~d}$
$18.8 \mathrm{~b}$
$3.09 \mathrm{abc}$
$49.5 \mathrm{a}$ 

Range
(15.6-29.4)
(11.9-26.8)
(1.82-4.48)
(17.9-80.1)
CV
26.9
27.9
36.1
50.6

Hybrids with primary genepool (GP1)

$\begin{array}{lcccc}\text { Mean } & 12.8 \mathrm{ab} & 9.9 \mathrm{a} & 2.34 \mathrm{a} & 73.9 \mathrm{~b} \\ \text { Range } & (9.4-17.9) & (7.2-15.4) & (1.32-3.87) & (64.7-83.1) \\ \mathrm{CV} & 15.5 & 23.1 & 28.3 & 7.8\end{array}$

Hybrids with secondary genepool (GP2)

$\begin{array}{lcccc}\text { Mean } & 12.3 \mathrm{ab} & 15.6 \mathrm{ab} & 3.39 \mathrm{~b} & 54.2 \mathrm{a} \\ \text { Range } & (7.4-17.4) & (8.5-30.25) & (2.50-4.32) & (36.8-79.7) \\ \mathrm{CV} & 23.0 & 34.7 & 13.8 & 18.5 \\ F \text {-ratio } & 13.7 & 7.25 & 5.71 & 16.63 \\ \text { Probability of } F & <0.0001 & <0.0001 & 0.0002 & <0.0001\end{array}$

${ }^{\mathrm{a}}$ Means within rows separated by different letters are significantly different according to the Duncan's multiple range test at $\mathrm{P}<0.05$. 


\section{Table 3}

Mean, range (between brackets), and coefficient of variation $(\mathrm{CV} ; \%)$ for flesh colour CIELAB colour parameters $\mathrm{L}^{*}{ }_{0}, \mathrm{a}^{*}{ }_{0}, \mathrm{~b}^{*}{ }_{0}, \mathrm{degree}$ of whiteness $\left(\mathrm{DW}_{0}\right)$, polyphenol oxidase activity (PPO), liquid extract browning (LEB), degree of browning (DB) and colour difference (CD) in accessions of cultivated eggplant $(S$. melongena; $n=6)$, wild relatives of the primary $(n=3)$, secondary $(n=18)$ and tertiary $(n=6)$ genepools and interspecific hybrids between cultivated eggplant and wild relatives from the primary genepool ( $\mathrm{n}=18)$ and secondary genepool $(n=24)$ and significance of mean differences among the six groups.

\begin{tabular}{|c|c|c|c|c|c|c|c|c|}
\hline Accessions & $\mathrm{L}_{0}^{*}$ & $\mathrm{a}_{0}^{*}$ & $\mathrm{~b}_{0}^{*}$ & $\mathrm{DW}_{0}$ & PPO & LEB & DB & $\mathrm{CD}$ \\
\hline \multicolumn{9}{|c|}{ Cultivated eggplant } \\
\hline Mean & $82.7 \mathrm{~d}$ & $-2.65 \mathrm{a}$ & $14.6 \mathrm{ab}$ & $23.0 \mathrm{a}$ & $1.92 \mathrm{a}$ & $3.35 \mathrm{a}$ & $4.09 \mathrm{a}$ & $5.91 \mathrm{a}$ \\
\hline Range & $(78.7-85.7)$ & $(-6.66-(-1.12)$ & $(10.2-20.7)$ & $(17.8-29.8)$ & $(1.34-2.87)$ & $(0.80-5.67)$ & $(2.71-5.64)$ & $(4.08-7.98)$ \\
\hline $\mathrm{CV}$ & 3.2 & 79.0 & 30.5 & 20.8 & 27.4 & 48.0 & 28.8 & 27.2 \\
\hline \multicolumn{9}{|c|}{ Wild primary genepool (GP1) } \\
\hline Mean & $67.3 \mathrm{c}$ & $-1.36 \mathrm{a}$ & $16.5 \mathrm{bc}$ & $36.9 \mathrm{~b}$ & $2.71 \mathrm{ab}$ & $5.52 \mathrm{ab}$ & $9.28 \mathrm{~b}$ & $11.29 \mathrm{ab}$ \\
\hline Range & $(62.2-76.5)$ & $(-2.19-(-0.67)$ & $(14.7-18.9)$ & $(27.8-42.4)$ & $(1.48-4.79)$ & $(4.70-6.25)$ & $(7.93-11.37)$ & $(9.46-12.9)$ \\
\hline $\mathrm{CV}$ & 11.9 & 56.9 & 13.4 & 21.5 & 66.8 & 14.1 & 19.8 & 15.4 \\
\hline
\end{tabular}

Wild secondary genepool (GP2) 


$\begin{array}{lcccccccc}\text { Mean } & 55.1 \mathrm{~b} & -2.4 \mathrm{a} & 20.6 \mathrm{~d} & 49.8 \mathrm{c} & 9.63 \mathrm{bc} & 4.23 \mathrm{ab} & 5.80 \mathrm{ab} & 9.33 \mathrm{ab} \\ \text { Range } & (47.4-60.2) & (-6.49-4.21) & (17.6-24.0) & (46.0-55.8) & (1.61-41.26) & (2.80-5.95) & (3.12-10.43) & (5.50-15.89) \\ \text { CV } & 8.4 & 149.1 & 9.9 & 7.6 & 121.3 & 25.4 & 49.1 & 40.9\end{array}$

Wild tertiary genepool (GP3)

$\begin{array}{lcccccccc}\text { Mean } & 46.1 \mathrm{a} & -1.71 \mathrm{a} & 18.8 \mathrm{~cd} & 57.6 \mathrm{~d} & 16.59 \mathrm{c} & 6.19 \mathrm{~b} & 7.01 \mathrm{ab} & 11.36 \mathrm{ab} \\ \text { Range } & (41.5-55.0) & (-9.40-6.94) & (16.6-22.5) & (51.0-60.1) & (4.11-38.79) & (0.95-14.41) & (2.07-12.96) & (2.72-20.16) \\ \text { CV } & 10.0 & 311.4 & 11.6 & 6.1 & 82.3 & 66.8 & 60.6 & 54.3\end{array}$

Hybrids with primary genepool (GP1)

$\begin{array}{lcccccccc}\text { Mean } & 80.5 \mathrm{~d} & -1.84 \mathrm{a} & 13.7 \mathrm{a} & 24.4 \mathrm{a} & 2.29 \mathrm{a} & 3.94 \mathrm{ab} & 5.33 \mathrm{ab} & 6.93 \mathrm{a} \\ \text { Range } & (69.7-85.8) & (-7.09-4.28) & (11.1-17.3) & (18.4-40.6) & (1.42-4.45) & (1.57-6.87) & (2.30-12.36) & (3.11-13.74) \\ \mathrm{CV} & 7.4 & 153.6 & 15.3 & 22.7 & 40.1 & 26.7 & 56.2 & 44.0\end{array}$

Hybrids with secondary genepool (GP2)

$\begin{array}{lcccccccc}\text { Mean } & 62.5 \mathrm{bc} & -2.70 \mathrm{a} & 19.6 \mathrm{c} & 43.0 \mathrm{~b} & 6.07 \mathrm{ab} & 5.95 \mathrm{~b} & 9.42 \mathrm{~b} & 12.84 \mathrm{~b} \\ \text { Range } & (42.2-75.5) & (-7.50-0.62) & (15.3-23.8) & (30.9-60.3) & (0.57-34.02) & (1.70-11.10) & (4.17-30.53) & (6.63-39.38) \\ \mathrm{CV} & 15.4 & 87.0 & 11.8 & 19.0 & 117.1 & 40.6 & 57.1 & 52.1 \\ F \text {-ratio } & 38.72 & 0.29 & 18.58 & 47.39 & 5.28 & 3.59 & 3.47\end{array}$


Probability of

F

0.9153

$<0.0001$

$<0.0001$

0.0004

0.0064

0.0078

0.0035

${ }^{a}$ Means within rows separated by different letters are significantly different according to the Duncan's multiple range test at $\mathrm{P}<0.05$. 


\section{Table 4}

Pairwise Pearson linear correlations based on within-group residuals of total accession and hybrid means $(n=70)$ for the traits studied: dry matter content, chlorogenic acid content, (CGA), percentage $(\%)$ of CGA peak area, CIELAB fruit flesh colour parameters $\mathrm{L}^{*}{ }_{0}, \mathrm{a}^{*}{ }_{0}$, $\mathrm{b}^{*}$, degree of whiteness $\left(\mathrm{DW}_{0}\right)$, polyphenol oxidase activity (PPO), liquid extract browning (LEB), degree of browning (DB), and colour difference (CD).

\begin{tabular}{|c|c|c|c|c|c|c|c|c|c|c|c|}
\hline & Total & & $\%$ CGA & & & & & & & & \\
\hline & phenolics & CGA & peak area & $\mathrm{L}^{*}{ }_{0}$ & $\mathrm{a}^{*}{ }_{0}$ & $\mathrm{~b}^{*}{ }_{0}$ & $\mathrm{DW}_{0}$ & PPO & LEB & DB & $\mathrm{CD}$ \\
\hline Dry matter & $0.032^{\mathrm{ns}}$ & $-0.218^{\mathrm{ns}}$ & $-0.188^{\text {ns }}$ & $0.019^{\mathrm{ns}}$ & $0.077^{\mathrm{ns}}$ & $-0.126^{\mathrm{ns}}$ & $-0.052^{\mathrm{ns}}$ & $-0.233^{\mathrm{ns}}$ & $0.006^{\mathrm{ns}}$ & $-0.074^{\mathrm{ns}}$ & $-0.102^{\mathrm{ns}}$ \\
\hline Total phenolics & & $0.401^{* * *}$ & $-0.263^{*}$ & $-0.070^{\mathrm{ns}}$ & $-0.107^{\mathrm{ns}}$ & $-0.161^{\mathrm{ns}}$ & $0.032^{\mathrm{ns}}$ & $-0.218^{\mathrm{ns}}$ & $0.111^{\mathrm{ns}}$ & $0.082^{\mathrm{ns}}$ & $-0.003^{\mathrm{ns}}$ \\
\hline CGA & & & $0.004^{\mathrm{ns}}$ & $-0.140^{\mathrm{ns}}$ & $-0.168^{\mathrm{ns}}$ & $-0.118^{\mathrm{ns}}$ & $0.113^{\mathrm{ns}}$ & $0.109^{\mathrm{ns}}$ & $0.099^{\mathrm{ns}}$ & $-0.030^{\mathrm{ns}}$ & $-0.040^{\mathrm{ns}}$ \\
\hline$\%$ CGA peak area & & & & $-0.135^{\mathrm{ns}}$ & $0.337^{* *}$ & $-0.134^{\mathrm{ns}}$ & $0.117^{\mathrm{ns}}$ & $-0.139^{n s}$ & $-0.263^{*}$ & $-0.393^{* * *}$ & $-0.393^{* * *}$ \\
\hline $\mathrm{L} *_{0}$ & & & & & $-0.118^{\mathrm{ns}}$ & $0.125^{\mathrm{ns}}$ & $-0.977^{* * *}$ & $-0.197^{n s}$ & $0.089^{\mathrm{ns}}$ & $0.151^{\mathrm{ns}}$ & $0.157^{\mathrm{ns}}$ \\
\hline $\mathrm{a}^{*} 0$ & & & & & & $-0.191^{\mathrm{ns}}$ & $0.053^{\mathrm{ns}}$ & $-0.247^{*}$ & $-0.241^{*}$ & $-0.197^{\mathrm{ns}}$ & $-0.284^{* *}$ \\
\hline $\mathrm{b}^{*}{ }_{0}$ & & & & & & & $0.079^{\mathrm{ns}}$ & $0.050^{\mathrm{ns}}$ & $0.170^{\mathrm{ns}}$ & $0.241^{*}$ & $0.327^{* *}$ \\
\hline $\mathrm{DW}_{0}$ & & & & & & & & $0.217^{\mathrm{ns}}$ & $-0.066^{\mathrm{ns}}$ & $-0.114^{\mathrm{ns}}$ & $-0.100^{\mathrm{ns}}$ \\
\hline PPO & & & & & & & & & $0.190^{\mathrm{ns}}$ & $0.404^{* * *}$ & $0.458^{* * *}$ \\
\hline
\end{tabular}


$\overline{\mathrm{ns}}, *, * *, * * *$ indicate non-significant, or significant at $\mathrm{P}=0.05,0.01$ and 0.001 , respectively. 


\section{Table 5}

Heterosis in interspecific hybrids over mid parent values $(\% ; \pm \mathrm{SE})$ based on parental accession (cultivated eggplant vs. wild species) and interspecific hybrids with primary (GP1; S. insanum) and secondary (GP2; rest of species) genepool species means for the traits studied: dry matter content, soluble refractometric residue (SRR), chlorogenic acid content, (CGA), CGA peak area (\%), CIELAB fruit flesh colour parameters $\mathrm{L}_{0}{ }_{0}, \mathrm{a}^{*_{0}}, \mathrm{~b}^{*} 0$, degree of whiteness $\left(\mathrm{DW}_{0}\right)$, polyphenol oxidase activity (PPO), liquid extract browning (LEB), degree of browning (DB), and colour difference (CD).

\begin{tabular}{|c|c|c|c|c|c|c|c|}
\hline \multirow[b]{2}{*}{ Traits } & \multirow{2}{*}{$\begin{array}{c}\text { GP1 } \\
\text { S. insanum }\end{array}$} & \multicolumn{6}{|c|}{ GP2 } \\
\hline & & S. anguivi & S. dasyphyllum & S. incanum & S. lichtensteinii & S. linnaean & S. tomentosum \\
\hline $\bar{n}$ & 18 & 10 & 1 & 4 & 6 & 1 & 2 \\
\hline Dry matter & $-2.9 \pm 3.6$ & $-35.8 \pm 6.6$ & 0.0 & $12.4 \pm 12.8$ & $-16.6 \pm 7.4$ & 41.6 & $-31.6 \pm 14.1$ \\
\hline Total phenolics content & $-23.3 \pm 5.2$ & $16.9 \pm 10.2$ & -24.6 & $52.5 \pm 17.1$ & $19.9 \pm 9.3$ & 21.8 & $73.9 \pm 25.1$ \\
\hline CGA & $-21.8 \pm 5.7$ & $76.5 \pm 17.8$ & 4.6 & $1.5 \pm 6.9$ & $11.5 \pm 3.5$ & 4.9 & $38.5 \pm 8.2$ \\
\hline$\%$ CGA peak area & $-2.8 \pm 1.4$ & $-6.4 \pm 5.8$ & -35.8 & $-20.5 \pm 3.9$ & $-25.7 \pm 5.0$ & -27.5 & $-17.8 \pm 11.8$ \\
\hline $\mathrm{L}_{0}^{*}$ & $7.4 \pm 1.6$ & $-16.0 \pm 3.3$ & -0.1 & $6.6 \pm 1.6$ & $-2.3 \pm 2.7$ & -17.7 & $-36.4 \pm 2.2$ \\
\hline$a_{0}^{*}$ & $-9.5 \pm 41.4$ & $118.7 \pm 203.2$ & 159.6 & $-3.3 \pm 25.1$ & $646.3 \pm 591.9$ & -19.1 & $-27.2 \pm 51.3$ \\
\hline $\mathrm{b}^{*}{ }_{0}$ & $-9.7 \pm 4.4$ & $3.0 \pm 6.4$ & 12 & $27.7 \pm 8.0$ & $17.9 \pm 5.8$ & 43.9 & $-7.4 \pm 5.3$ \\
\hline
\end{tabular}




\begin{tabular}{lrrrrrrrr} 
DW & $-18.2 \pm 3.8$ & $27.4 \pm 5.3$ & 4.9 & $-4.6 \pm 3.5$ & $8.5 \pm 5.0$ & 39.9 & $55.4 \pm 2.1$ & -13.7 \\
PPO & $16.5 \pm 17.8$ & $65.6 \pm 27.9$ & 221 & $50.3 \pm 81.1$ & $23.8 \pm 32.5$ & $187.3 \pm 42.1$ \\
LEB & $-7.8 \pm 7.0$ & $93.2 \pm 24.6$ & 51.5 & $68.0 \pm 47.9$ & $33.1 \pm 22.2$ & 46.6 & $35.8 \pm 47.7$ \\
DB & $-16.8 \pm 12.8$ & $85.9 \pm 20.2$ & 287.8 & $224.6 \pm 48.1$ & $138.6 \pm 26.6$ & 143.9 & $-9.1 \pm 8.5$ \\
CD & $-19.1 \pm 8.6$ & $55.9 \pm 10.6$ & 242.3 & $175.9 \pm 37.9$ & $124.4 \pm 19.5$ & 106.6 & $-10.9 \pm 6.8$ \\
\hline
\end{tabular}



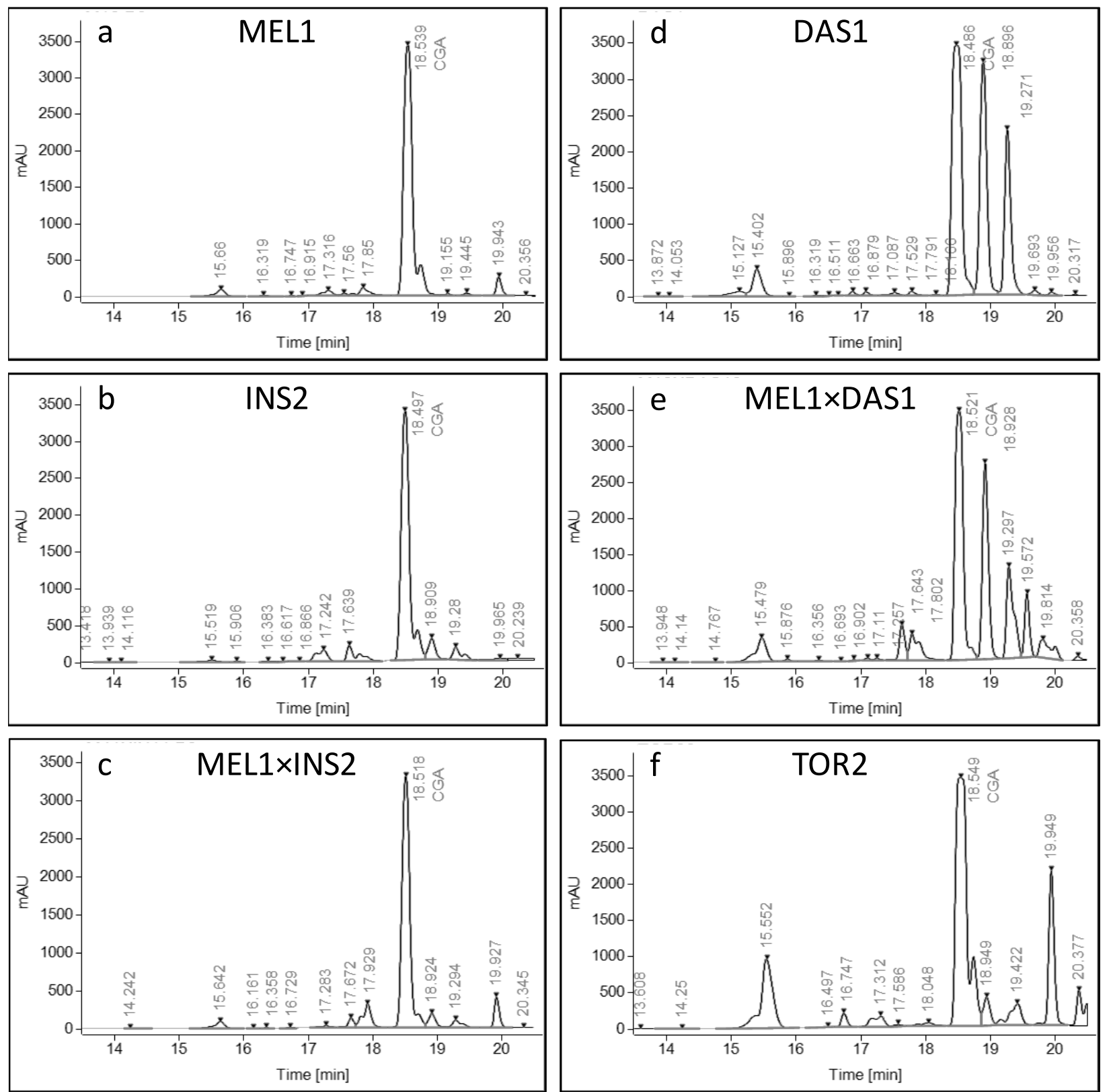

Fig. 1. Representative high performance liquid chromatography chromatograms of phenolic compounds (detected at $325 \mathrm{~nm}$ ) in different materials evaluated, including: a) cultivated eggplant (S. melongena MEL1), b) one primary genepool accession (S. insanum INS2), c) the interspecific hybrid MEL1 $\times$ INS2, d) one secondary genepool accession $(S$. dasyphyllum DAS1), e) the interspecific hybrid MEL1 $\times$ DAS1, and f) one tertiary genepool accession $(S$. torvum TOR2). The chlorogenic acid peak (CGA) is indicated. 

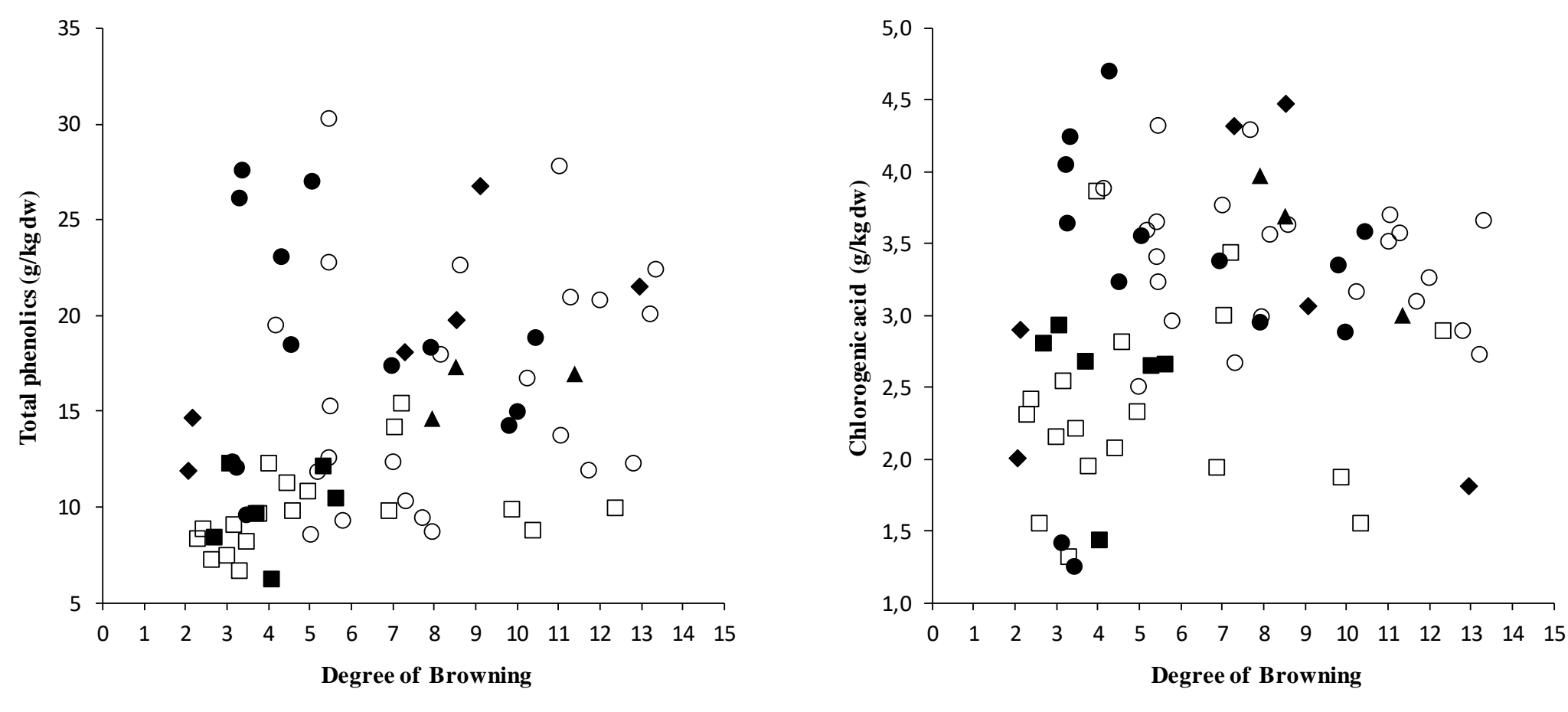

- Cultivated $\triangle \mathrm{GP1} \bullet \mathrm{GP2} \bullet \mathrm{GP3} \square \mathrm{HGP1}$ OHGP2

- Cultivated $\triangle \mathrm{GP1} \bullet \mathrm{GP2} \bullet \mathrm{GP3}$ 口 HGP1 O HGP2

Fig. 2. Relationships between the degree of browning ( $x$-axis) with: a) total phenolics content ( $\mathrm{g} / \mathrm{kg} \mathrm{dw}$, $\mathrm{y}$-axis; left graph), and b) chlorogenic acid content ( $\mathrm{g} / \mathrm{kg} \mathrm{dw}, \mathrm{y}$-axis, right graph), in a collection of accessions of cultivated eggplant (ם), wild relatives of the primary (GP1; $\mathbf{\Delta})$, secondary (GP2; •), and tertiary genepools (GP3; •), and of interspecific hybrids between cultivated eggplant and wild relatives of primary (HGP1; $\square$ ) and secondary genepool (HGP2; o) respectively. One outlier data with DB above 30 was not included in the figure. 